\title{
Research on the Civil Liability System of the Anti-Monopoly Law in
}

\section{China}

\author{
Shantao $\mathrm{Hao}^{1, \mathrm{a}}$ \\ ${ }^{1}$ Tianjin University, Tianjin, 300073, China
}

Keywords:Anti-monopoly, Civil liability, Operators

\begin{abstract}
The basic objective of the civil liability system of the anti-monopoly law is to prevent the occurrence of the illegal monopolyand to punish illegal monopoly behaviors. However, the civil liability system of the anti-monopoly law in our country is relatively rough and the operability is also relatively weak. According to the problem of anti-monopoly law in Chinaanalyzed in this paper, the improvement measures of the civil liability system of our country's anti-monopoly law are provided, includingestablishing system of diversified civil liability, building institution of double damage compensation and reducing proof burden of monopoly case plaintiff.
\end{abstract}

\section{Introduction}

Anti-monopoly law is to rely on the legal responsibility of the pursuit to achieve the regulation of a variety of behaviors of restricting competition in the market economy, the pursuit of civil liability is one of the important part of the establishment of the world or regional anti-monopoly law therefore attaches great importance to the provisions of the civil liability system. China's anti-monopoly law in the content of the civil liability of the provisions of the relatively simple, and set up the relevant system, there are many worthy of our in-depth study. The competition of enterprises is the direct embodiment of the core value of anti-monopoly law, and also the target of the anti-monopoly law. Anti-monopoly law stipulates that all liabilities are legal barriers to market competition in the behavior of the price should be paid, because the market competition is not the civil rights prescribed by the civil law. Therefore, the civil liability of the anti-monopoly law can protect the scope of the object which is beyond the scope of the general civil liability, which reflects the independent character. The purpose of civil liability legislation in order to fill in the common law civil violations caused by the victims of persons and property damage, the victim harmed by illegal actors or the property or personal interests, through direct accountability related to civil liability for violations of people. Therefore, the main role of general civil liability is to fill the damage. However, in view of the anti-monopoly law, the main purpose of the legislation is to protect the freedom of competition in the national market, so only to fill the victim's damage, it cannot fully achieve its legislative purposes. The purpose of the purpose of filling up the damage cannot fully compensate for the loss suffered by each victim, but also cannot play a role in binding and deterrence of monopolistic behavior and restrictive competition behavior. Therefore, from the perspective of safeguarding the interests of the whole society, the civil liability system of the anti-monopoly law must achieve the purpose of preventing illegal acts.

\section{Deficiencies of Current Civil Liability System of the Anti-Monopoly Law in China}

Single Form ofCivil Liability. The loss caused by the provisions of the anti-monopoly law is the basis of the civil liability of the behavior subject. So, this understanding can be excluded in the law 
against the form of civil liability legal basis has not already caused to others loss, can also be taking place in the property damage, or even damage has not yet occurred but normal logic will result in the loss of the situation. Therefore, China's anti-monopoly law does not recognize the exclusion of the behavior of the main violations of this form of civil liability. The current world anti-monopoly law in many provisions of injunction and damages of the two types of civil means we say help exclusion against the form of liability is necessary for the implementation of the anti-monopoly law, can fundamentally curb illegal market competition, protect the normal order of market competition will not be shaken, these positive meaning is the damages cannot be replaced. This needs to be clarified in the subsequent legislative process. As long as the operator of the monopolistic behavior, causing losses to others, it may constitute a criminal offense. Although the provisions of this article shall be allowed to be investigated for criminal liability, the provisions of the constitution of crime are not clear. The stipulation of the subject, object and behavior of the crime is not clear, which directly leads to the difficulty of the operation. On the one hand, it will lead to excessive deterrence; on the one hand, it will bring about the phenomenon of insufficient deterrence, which leads to the criminal liability of anti-monopoly.

Inadequate Deterrent of Legally Bound.The anti-monopoly law of our country has set up a clear civil and administrative responsibility mechanism. However, because the law does not clearly stipulate that the victim has the right of punitive damages. It often leads to the lack of legal responsibility and low efficiency. It is necessary to set up the corresponding liability system for the anti-monopoly law enforcement agencies. But from the point of view of existing legal provisions, the specific obligations of their punishment is not clear, especially the lack of administrative law enforcement workers antitrust sanctions or penalties of compensatory liability provisions, but relatively vague roughly with the administrative sanction responsibility instead of administrative punishment, it is difficult to ensure the fairness and efficiency of the anti-monopoly legal responsibility for the. The criminal responsibility of China's anti-monopoly law does not specify a serious monopoly behavior, but only to the relevant personnel investigation set up monopoly hinder the corresponding criminal responsibility, criminal responsibility of illegal workers in the implementation of the anti-monopoly law enforcement agencies in the anti-monopoly regulations concise. Current legislation set the criminal responsibility of the investigation and Adjudication of prevent monopoly behavior and illegal implementation of anti-monopoly law, did not change the current penalty liability of the illegal monopoly actors is almost blank legislative defects. In addition to the collusion bidding the illegal monopoly agreement is adjusted by the criminal law and the provisions of the penalty responsibility specific, for other monopolistic behavior does not explicitly create measures corresponding criminal responsibility, the severe restrictions on competitive behavior regulation is a major liability of negligence and defects. The application of the anti-monopoly legal liability of the penalty punishment means will not be able to produce enough deterrent force.

Unreasonable Distribution of Evidential Burden. The distribution of burden of proof can be divided into two categories. As the monopoly agreement has a strong concealment, and the plaintiff is damaged by the monopoly agreement in the monopoly agreement does not have to exclude, restrict competition and other aspects of the lack of evidence may be expected. Therefore, the provisions of the defendant to deal with the agreement do not have to exclude, restrict the effect of competition bear the burden of proof. In addition, the provisions of the eighth paragraph of the second: the defendant to defend its behavior justified grounds should bear the burden of proof. This provision is the same as the seventh basis of the burden of proof, which is based on the difficulty of obtaining evidence. If this kind of burden of proof is distributed to the plaintiff, it is not conducive 
to the protection of the legitimate rights and interests of the parties. The plaintiff bears the burden of proof the interpretation of the first paragraph of article eighth and ninth of the burden of proof to make the relevant provisions. The plaintiff to the defendant has a dominant position and abuse of dominant market position to bear the burden of proof in the relevant market. In addition, the plaintiff should respond to the specific circumstances of the market structure and competitive conditions. Relatively speaking, the plaintiff needs to bear the burden of proof is much heavier than the defendant. In practice, due to the plaintiff and the defendant in the position and strength of the disparity, the plaintiff is difficult to obtain evidence. The distribution of burden of proof is unreasonable and needs to be redistributed.

\section{Improvement Measures of Civil Liability System of the Anti-Monopoly Law in China}

Establish System of Diversified Civil Liability.On the basis of the two forms of civil liability, such as the cessation of infringement and compensation for damages, China's anti-monopoly law can also set up various forms of civil liability, such as the elimination of danger, the elimination of infringement, and the apology. Stop infringement is only to stop the violations, and did not take into account the impact of the violations have been implemented, and the elimination of danger can make up for this loophole, so that the civil liability is more complete. Injunction and the first two together, cannot only regulate the monopoly behavior, but also to the infringement occurred to a good preventive effect, curb monopoly behavior from its source, the purpose of legislation more effectively realize the civil liability of anti-monopoly law. Apology is mainly applicable to the personal rights or property rights violations. In the civil action of monopolistic behavior, the victim will suffer the loss of property and the loss of spirit. Compensate for the loss only compensate the victim's material loss. The use of an apology and compensation for damages can better compensate the victim's mental and material loss. For the monopoly civil liability in many countries and regions, are based on the principle of no fault liability, if only the implementation of fault civil liability, business operators and consumers is not very good to protect the market competition in the damage to the legitimate rights and interests. Chinese mainland should establish civil liability system of fault liability and no fault liability with liability system, for the signing of the market between cartel, joint limit, enterprise behavior and administrative monopoly agreements and other alleged illegal monopolistic behavior directly applicable to no fault liability. And other market monopoly behavior is applicable to fault liability. It can effectively protect the legitimate rights and interests of enterprises and consumers, and the public interests of our society.

Build Institution of Double Damage Compensation. According to the current situation of our country, we should increase the punitive damages mechanism in the civil liability of the anti-monopoly law system. For the people who have a strong and strong psychology, they are generally lack of enthusiasm and enthusiasm for litigation. The proper introduction of punitive compensation system, can make the procedure not only can fully compensate for compensation due to its violations by the loss and costs due to the cost of litigation, the remaining even, this are not only to protect the victim, and to mobilize the masses initiative competitive action. We from the economics perspective, these penalties will lead to capital market in the domestic economy is reduced, not only cannot create interest, instead of the original to create increased interest costs out of the market, which is obviously contrary to the development of the market economy, does not comply with the legislative purpose of the competition law of our country. The punitive damages mechanism can improve the illegal cost, restrain and deter the potential offenders in the market. For the victims, this avoids the issue of too low compensation for non-prosecution, not only to compensate for the loss of the victims, but also mobilize the enthusiasm of the public to participate 
in litigation. There is no essential difference between the double compensation and the three times of compensation deterrence, but the deterrent effect of three times compensation may be better. However, the vast majority of enterprises in the international market competitiveness are not strong. Excessive punishment may have adverse effects on the development of enterprises, contrary to the purpose of the establishment of the civil liability system of China's anti-monopoly law.

Reduce Proof Burden of Monopoly Case Plaintiff.The monopolistic behavior of monopoly agreements and other serious violations of the order of competition applies the principle of no fault liability. The plaintiff does not need to assume the burden of proof for the defendant to implement such monopolistic behavior. The court may directly according to the anti-monopoly law enforcement agencies to determine the defendant to implement the monopolistic behavior. The plaintiff does not need to assume the burden of proof on the monopolistic behavior. The plaintiff may request the operator as the defendant to show the relevant evidence, thus produce the effect of inversion of burden of proof, and reduce the burden of proof of the plaintiff. If the defendant refuses to show relevant evidence, the court will face punitive sanctions. The court will force it to demonstrate relevant evidence. The defendant acts illegal, will also be punished. The principle of liability for fault or no fault liability does not accord with the basic aim of civil liability system of anti-monopoly law. But it also requires the victim to prove the subjective status of illegal agents. The victims are mostly in a weak position in the capacity of proof. There is a big difficulty in the collection of evidence. The principle of no fault liability can indeed reduce the burden of victims in a certain extent, but also make it possible for both parties to the litigation status inequality, ultimately unable to reflect and maintain a fair competition order in the anti-monopoly legislation value.

\section{Conclusion}

There are many provisions to be improved in today's anti-monopoly law in China. The improvement of civil liability system plays an important role in the implementation of anti-monopoly law. The world economy is changing constantly and our country is constantly changing. Correspondingly,the civil liability system of anti-monopoly law should keep pace with the times. We shouldestablish system of diversified civil liability, build institution of double damage compensation and reduce proof burden of monopoly case plaintiff to formulate a scientific system of civil liability in the anti-monopoly law in China.

\section{References}

[1] Li Guohai. On Distribution of Proof Responsibility in Civil Litigation of Anti-Monopoly LawWith the Review of Supreme Peopled Court's Judicial Interpretation of Anti-Monopoly Law [J].Journal of Graduate School of Chinese Academy of Social Sciences, 2014(1): 84-88.

[2] Zhang Lei. The Civil Liability of the Anti-Monopoly Law:The judicial interpretation of "antimonopoly law” [J]. Journal of Weinan Normal University, 2014, 29(5): 21-25.

[3] Liu Fucheng. Rationality Principle in Practice of Chinese Anti-Monopoly Law- Taking Uncertainty as Perspective [J]. Journal of Taiyuan University (Social Science Edition), 2016, 17(5):15-25.

[4] Zhang Ruiping. On the Identification of Civil Liabilities inAnti -Monopoly Law [J]. Journal of Beijing Jiaotong University (Social Sciences Edition), 2011, 10(2): 93-98. 
